\title{
'Go in peace - and die!' The task of the church in the HIV and/or AIDS context
}

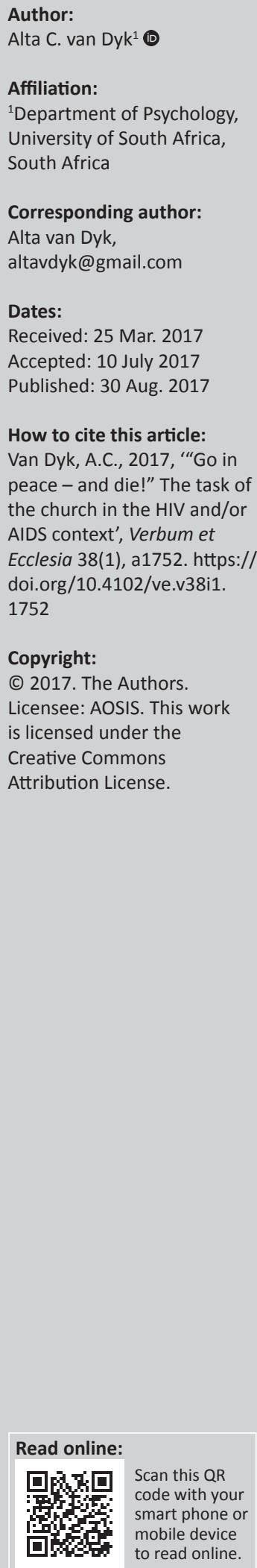

The purpose of this study was to investigate how the white Afrikaans-speaking churches in the Reformed tradition are dealing with the health and well-being of its parishioners in the $\mathrm{HIV}$ and/or AIDS context. An electronic questionnaire was filled in by 142 clergy from various Afrikaans-speaking churches. Results showed that clergy (90\%) believed that HIV and/or AIDS is a much bigger problem outside the Afrikaans-speaking church than inside the church. Although $66 \%$ agreed that HIV was also a problem in white Afrikaans-speaking churches, only $30 \%$ admitted that it was a problem in their own congregation. Most (70\%) believed that HIV and/or AIDS can be ignored in their own congregations. A small number of clergy took it on themselves to provide HIV and/or AIDS counselling (21\%), care (19\%) and education (18\%) with minimum support from church leaders. When it came to HIV and/or AIDS prevention, most clergy were only prepared to preach abstinence and faithfulness, with their main message that 'our bodies are the temple of God and that it should not be violated' (70\%). Is it not time for clergy to confront reality and to protect their flock by also teaching them prevention skills? Intradisciplinary and/or interdisciplinary implications: The article is relevant to the fields of pastoral care, psychology and HIV and/or AIDS.

Suppose a brother or a sister is without clothes and daily food. If one of you says to them, 'Go in peace; keep warm and well fed,' but does nothing about their physical needs, what good is it? (Ja 2:15-16; New International Version [NIV])

\section{Introduction}

Partly under the influence of Platonic philosophy, the church in the past tended to emphasise the spiritual health while largely ignoring the physical health of her members. In practice, this meant that although the church acknowledged her duty to take care of the physical needs of the poor and the sick, it seldom spilled over to a concern about the general physical health of members by actively promoting healthy lifestyles through prevention and behaviour change programmes.

More recently theologians have advocated a more holistic approach to pastoral care. The church can no longer be content to just 'show the way to heaven' - she also has a definite task in terms of the psychological and physical well-being of her flock (Janse van Rensburg 2010). This implies that the church should not only help after 'disaster has struck', but also help in preventing the disaster in the first place (Lasater et al. 1986:125-131).

Within the HIV and/or AIDS context this more holistic approach to pastoral care has become especially important because spiritual, psychological and physical needs are often so intertwined that the negligence of any one aspect may severely limit the success of pastoral care.

\section{HIV and/or AIDS and the white Afrikaans-speaking churches}

Much has been written during the past three decades about the role, successes and failures of the church to deal with the HIV and/or AIDS epidemic (Bryant-Davis et al. 2016:388-408; Gibbs, Campbell \& Maimane 2015:114-125; Moore et al. 2012:865-878; Stewart, Thompson \& Rogers 2016; Timmons 2009:92-102). The apathy, the increasing dissociation with social issues (including HIV and/or AIDS) within the church and a lack of a theology of HIV and/or AIDS has often been referred to in research on HIV and/or AIDS and the church (Mahlangu 2011:1-6; Thomas 2008:278; Van Dyk \& Van Dyk 2007:683; Van Wyngaard 2006:267). The important task of the church in taking the lead in a changing society, especially with challenges like HIV and/or AIDS, has also been emphasised. One of the major challenges, which public theology can no longer ignore, is therefore to develop Christian sexual ethics, 
with a focus on HIV and/or AIDS in the African context (Ferdinando 2016:113; Haspel 2004:480-498).

In the light of this the Synod of the Dutch Reformed Church (Nederduits Gereformeerde [NGK]) in South Africa made a decision in 2002 to actively participate in the battle against HIV and/or AIDS (Algemene Kommissie vir die Diens van Barmhartigheid 2002:534-535). One can, however, ask to what extent the NGK (and the other white Afrikaansspeaking churches) has succeeded in formulating a theology of HIV and/or AIDS, provide clear policies and provide sufficient support and training to assist clergy in managing HIV and/or AIDS in their congregations.

In a comprehensive survey in the NGK in 2006, it was found that only a small minority of parishes $(10 \%$ of the 602 included in the survey) were involved in HIV and/or AIDS work, and that their efforts were mainly focussed on black impoverished communities or non-members of their own congregations. About $90 \%$ of the congregations also indicated that they did not plan a community-based strategy for people living with HIV and/or AIDS in the future (Schoeman 2012:3). Schoeman therefore concluded that the NGK were moving away from involvement in the community and its well-being.

There may be many reasons why clergy and members of a congregation shy away from HIV and/or AIDS-related work, or to rather do it outside their own congregations. Of these reasons, stigmatisation and negative attitudes are probably the most important. On the one hand, people may believe that the scope of HIV and/or AIDS work in their own parishes is limited because of the fact that HIV-infected members of the congregation may be unwilling to reveal their status because they fear stigma and discrimination (Van Dyk \& Van Dyk 2007:686). Secondary stigmatisation, where clergy fear that they will be stigmatised themselves through association with HIV and/or AIDS issues, may also play a role in avoiding HIV and/or AIDS work or the preference to work outside their own congregations (Ogunmefun, Gillbert \& Schatz 2011:90).

Another reason not to be involved in HIV and/or AIDS work (or doing it mainly outside one's own congregation) may be based on the assumption that 'AIDS is not a problem in the Afrikaans-speaking churches'. For example, in a publication titled 'Die wit kerk en die swart nood', the following comment was made. One could only hope that this view has since changed:
... die wit kerke (en by name die NG Kerk) is meer verteenwoordigend van die huidige middelklas, meer bejaarde, wit gemeenskap. Die teikengroep wat die felste getref word deur MIV/Vigs word dus nie binne die wit kerk verteenwoordig nie. [... the white church (with reference to the NGK) is more representative of the current middle class, mainly elderly and white community. The target group who is the hardest hit by HIV/AIDS, is not part of the white church.] (Schoeman, Verster \& Kritzinger 2002:469, [author's own translation])

As suggested earlier, perceptions about the supposed limited role of the church in promoting the physical well-being of their members may also play a role in preventing ministers and congregations from becoming involved in the HIV and/ or AIDS field. Responsibility for preventing disease and promoting the physical well-being of their members is thereby shifted away from the domain of the church, to that of the medical and social work professions. Olivier (2014:253) is of the opinion that the church was 'pushed out' of public health as a result of factors such as secularism and modernisation which saw the church as irrelevant in modern public life.

Denis made the observation that the church in South Africa has historically been more involved in providing care and support to people living with HIV and/or AIDS, rather than in $\mathrm{HIV}$ and/or AIDS prevention campaigns (Denis 2009:67). He attributed this to the fact that HIV and/or AIDS prevention became completely disconnected from the aspects of care and support because of the moralistic message of the church. Even if considerable resources are made available to the church, it is seldom used for peer education programmes and HIV and/or AIDS information and prevention campaigns (Denis 2009:74). By moralising HIV and/or AIDS and by associating it with sexual promiscuity, the church may also inadvertently have contributed to the stigma associated with the disease.

The purpose of this research project was to investigate how the white Afrikaans-speaking churches in the Reformed tradition (specifically the clergy) are dealing with the health and well-being of its parishioners in the HIV and/or AIDS context. The research questions were as follows:

- Do ministers think that HIV and/or AIDS is a problem in the Afrikaans-speaking church in general and in their own congregations in specific?

- Do they feel empowered to deal with HIV and/or AIDS?

- Do they think that they receive sufficient guidance and support from their church leaders, synods or organisations, and what kind of guidance and support (if any) do they require?

- Do they think that it is the task of the church to be involved in HIV and/or AIDS education and prevention programmes?

- To what extent are they and their congregations involved with HIV and/or AIDS programmes, both inside and outside their parishes and what reasons do they give for not being involved?

- What should be the content and main message of such education and prevention programmes? Do they think that general religiosity is sufficient to protect church members from HIV infection and that preaching morals are therefore sufficient?

- Which beliefs about HIV and/or AIDS are prevalent amongst clergy? For example, do they believe that religious people are less inclined to become HIV infected?

The above questions are of critical importance if one agrees with the view that it is primarily at the level of the individual congregations: 
that the fight against HIV and AIDS will or will not be successful by contributing to behaviour change, stigma reduction, higher levels of disclosure, care and treatment and ongoing support to people living with HIV and AIDS. (Denis 2009:111)

\section{Research design}

An empirical survey was conducted amongst clergy in the white Afrikaans-speaking churches in the Reformed tradition to determine how they are dealing with HIV and/or AIDS in their congregations. Emails were sent to all clergy whose email addresses were available on the Internet and in church publications. The purpose of the research was explained to clergy and, if they were willing to participate in the research, they received a link to a Web address where they could complete an electronic online questionnaire.

\section{Sample}

The sample consisted of clergy within the white Afrikaansspeaking churches in the Reformed tradition in southern Africa. It, therefore, included ministers in the 'Nederduits Gereformeerde' (NGK), 'Nederduitsch Hervormde' (Herv), 'Gereformeerde' (Geref) and 'Afrikaanse Protestantse' (APK) churches in South Africa, Namibia and Zimbabwe with available email addresses $(n=2543)$. The sample should be seen as a convenient sample (Coolican 2004:42) because it excluded all clergy without email addresses. Although sampling attempted to avoid any bias in terms of gender, age and geographic location, it should be noted that the results will mostly reflect the views of older white Afrikaansspeaking men because of the nature of the population sampled - for historical reasons the clergy in these churches are mostly male and above 40 years of age.

It was clearly stated to the participants that they were under no obligation to fill in the questionnaires. Because of the nature of the electronic survey, their anonymity and the names of their congregations were guaranteed because neither would be known to the researcher. Ethical clearance for the research was obtained by the Department of Psychology and the College of Human Sciences at Unisa.

\section{Measuring instrument}

A structured electronic questionnaire (with some open questions) developed in Google Forms was used for the survey. Participants only had to click on the answer of their choice or type in their answers for open questions. Closed questions were mainly in the format of ordinal four-point Likert scales ranging from 'strongly agree' to 'strongly disagree' with a few 'Yes or No' questions. Data from Google Forms were directly exported error-free to IBM SPSS Statistics for data analysis.

Over and above basic demographic information (age, gender, highest theological qualification, church affiliation and city or rural congregation) each one of the research questions (see above) was addressed in the questionnaire (the extent to which HIV and/or AIDS is a problem [10-item scale], empowerment, support by leaders and synods, involvement with HIV and/or AIDS initiatives, the main theological message to share with their parishioners and beliefs about HIV and/or AIDS).

\section{Techniques of data analysis}

Descriptive and inferential statistical analysis was performed by using the software programme IBM SPSS version 24 . Principle component analysis (PCA) was performed on fourpoint Likert scales to extract factors or components. One scale, namely 'HIV and/or AIDS is a problem' (with 10 items) was extracted $(\mathrm{KMO}=0.747$, Chronbach's Alpha $=0.816)$. The scale ranged between 1 (strongly disagree) and 4 (strongly agree).

The results of all other questions are reported as frequencies for 'disagree' (1) or 'agree' (2). Non-parametric statistical procedures such as the Mann-Whitney $U$ test and the Kruskal-Wallis test were used to calculate possible differences between groups (e.g. males or females, church affiliations). The level of significance was set at 0.05 .

\section{Results}

\section{Demographic attributes of participants}

The questionnaire was completed by 142 participants, representing a return rate of $5.6 \%$. The mean age of clergy who participated in the study was 52.28 years $(\mathrm{SD}=11.46$; minimum age $=25$ and maximum age $=75$ ) with $81 \%$ being older than 40 years. Most of the participants were men $(91.5 \%)$ with only $8.5 \%$ being women (which is a fair reflection of this male-dominant occupation). Most of the participants (69\%) had a Master's degree or higher. Most of the clergy was in the NGK Church (76.8\%), with $9.9 \%$ in the Herv Church, 9.2\% in the Geref Church and $4.2 \%$ in the APK Church. Most of participants ministered to congregations located in cities or major towns $(65.5 \%)$, with $34.5 \%$ of congregations being in rural areas.

\section{Is HIV and/or AIDS a problem in Afrikaans-speaking churches?}

The mean score on the 'HIV and/or AIDS is a problem' scale was $2.48(\mathrm{SD}=0.46 ; n=142$, range $=1-4)$. There was a relatively large variation in opinions on this issue, with a minimum score of 1.4 (HIV and/or AIDS is not a problem) to a maximum of 3.6 (HIV and/or AIDS is a problem).

The following groups of clergy were significantly MORE inclined to see HIV and/or AIDS as a problem in the Afrikaans-speaking churches: female clergy (median [md] = 3.0) versus male $(\mathrm{md}=2.5)(U=326, z=-3.322, p=0.001)$; clergy with higher (honours and above) academic qualifications $(\mathrm{md}=2.5)$ versus those with lower qualifications $(\mathrm{md}=2.3)\left(\chi^{2}=9.195, d f=3, n=141, p=0.027\right)$; clergy from the three 'sister' churches $\left(\chi^{2}=14.138, d f=3, n=141, p=0.003\right.$ ) versus the APK Church. Medians were: APK = 1.95; Geref = 2.4; Herv Church = 2.4; NGK = 2.5). 
The findings can be summarised by saying that male clergy, clergy with only a B-degree and clergy from the APK Church were less likely to believe that HIV and/or AIDS is a problem in the Afrikaans-speaking churches.

A closer look at the frequencies of some of the individual items in the 'HIV and/or AIDS is a problem' scale revealed the following interesting tendency: $90.2 \%$ of participants believed that HIV and/or AIDS was a bigger problem outside white Afrikaans-speaking churches than inside their church; $66 \%$ of participants admitted that HIV and/or AIDS was nonetheless a problem in white Afrikaans-speaking churches in general; and only $30.3 \%$ believed that HIV and/or AIDS was also a problem in their specific parishes. Most (69.7\%) of the ministers felt that the number of people living with HIV and/or AIDS is so small in their own congregation that the problem can be ignored, notwithstanding the fact that $62 \%$ of them admitted that they know or suspect that there are HIVpositive people in their congregations.

\section{Empowerment of clergy}

A more general question asked if clergy felt sufficiently equipped (trained) to counsel people with HIV infection. Most (61.3\%) said 'yes', while 9.2\% said 'absolutely not' and $29.6 \%$ said that they 'feel very uncertain' about counselling people with HIV and/or AIDS. The answer to the more specific question if they felt knowledgeable to share HIV and/or AIDS information (e.g. causes, prevention and management) with their parishes, clergy were not as positive. Most (52.1\%) said 'yes', 5.6\% said 'absolutely not' and 42.3\% said they were uncertain on how to provide HIV and/or AIDS education.

\section{Support and guidance to clergy}

On the question 'to what extent do you get support and guidance from church leaders and synod', 21.1\% said they get absolutely no support. If they want to know something they must do their own research. A further $44.4 \%$ said they get 'very little' support, while $33.8 \%$ thought they received 'enough' support. This means that $65.5 \%$ of clergy received no or very little support from their church leaders or synod with regard to HIV and/or AIDS. Only $12 \%$ of the participants received support from other organisations such as the Christian AIDS Bureau of South Africa. Support from these organisations included training workshops, information pamphlets, advice and references to other organisations where they can access help.

Just more than half of the participants (52.1\%) indicated that they want support (or already receive support) from the church, while $40.1 \%$ said that they do not want any HIV and/ or AIDS support from church leaders. The reasons given for not wanting support were as follows: (1) 'I am not interested in any information or support regarding AIDS' (58\%, 33/57), (2) 'There are no HIV-positive people in my parish' (30\%) and (3) 'I would rather refer HIV-positive parishioners to doctors than to cope with them myself' (5.3\%). Some clergy commented that it is the task of doctors and hospitals to deal with HIV and/or AIDS prevention and care, and that the roles of church and medical systems should stay separate.

Participants who wanted support asked for the following: (1) training on how to educate people on all aspects of HIV and/ or AIDS (including prevention), (2) training on how to counsel HIV-infected people, (3) reading material and a referral network, (4) clear policy guidelines from synod and more public discourse from church leaders on HIV and/or AIDS. Most clergy (79.5\%) felt strongly that the church should implement a comprehensive strategy to change misconceptions about HIV and/or AIDS and address negative attitudes and stigmatisation of people living with HIV and/or AIDS and (5) guidelines from leadership on how to give guidance on sexual issues where there is a clear discrepancy between the official message of the church and that of the medical professions.

There were significant differences between clergy who wanted support from the church and those who did not want any support. Clergy who did not want any support tended to believe that: (1) HIV and/or AIDS is not a problem in the Afrikaans-speaking church $(U=1456, z=-2.940, p=0.003$, md $=2.4$ [do not want support] versus 2.6 [want support]), (2) parishioners 'know that sex outside marriage is sin, and therefore it is not necessary to give them any further information' ( $U=1760, z=-2.109, p=0.035$, mean rank $=$ 59.88 versus 70.72 and (3) it is not the task of the church to educate people on high-risk behaviour and the prevention thereof $(U=1550.5, z=-2.980, p=0.003$, mean rank $=56.2$ versus 73.55).

\section{Involved in HIV and/or AIDS projects}

A total of $40.8 \%$ of the clergy and parishes were involved in $\mathrm{HIV}$ and/or AIDS projects, while $59.2 \%$ were not involved in any HIV and/or AIDS work. Involvement in HIV and/or AIDS projects were as follows: (1) 19\% were involved in HIV and/or AIDS projects exclusively outside the borders of their own parishes, (2) $17.6 \%$ of the projects were both inside and outside their own congregations while (3) $4.2 \%$ were exclusively inside own congregations (see Figure 1).

The type and places of clergy's and their congregation's involvement in various HIV and/or AIDS projects are summarised in Table 1. Most clergy were involved in more than one activity. Clergy or their congregations were involved in the following HIV and/or AIDS activities or projects.

Counselling: The HIV and/or AIDS activity that clergy engaged in the most was counselling of HIV-positive individuals and their families (21.1\%). Counselling was mainly offered inside the clergy's own congregation, with $10.6 \%$ who offered counselling exclusively within their own parishes, $9.1 \%$ who offered counselling both inside and outside their own congregations and only $1.4 \%$ who said that they counsel exclusively outside their own congregations. 
Anti-stigma campaigns: Active efforts to address and change stigma and negative attitudes towards HIV-positive people were reported by $20.4 \%$ of clergy. Efforts to change attitudes took place inside as well as outside the clergy's own congregations, with only $2.8 \%$ clergy who worked exclusively outside their own congregations to change negative attitudes.

Preach and pray: Only $19.7 \%$ clergy who participated in the study said that they sometimes give attention to HIV and/or AIDS issues during sermons and prayer meetings. Attention to HIV and/or AIDS in sermons and in prayer meetings mostly occurred within the clergy's own congregations $(10.6 \%)$. The exact nature and content of the HIV and/or AIDS messages were not reported.

Care: Home-based care and support of people living with HIV and/or AIDS (e.g. looking after the children, cooking for the family, taking patients to the clinic) were provided by $19 \%$ of the participating clergy or their congregations. Assistance with the livelihood of families affected by HIV and/or AIDS (e.g. food, clothes, money) was provided by $18.3 \%$ of the clergy, while $19.7 \%$ supported orphans. Orphan care was mainly provided to children outside the clergy's parishes, while assistance with home care and livelihood was

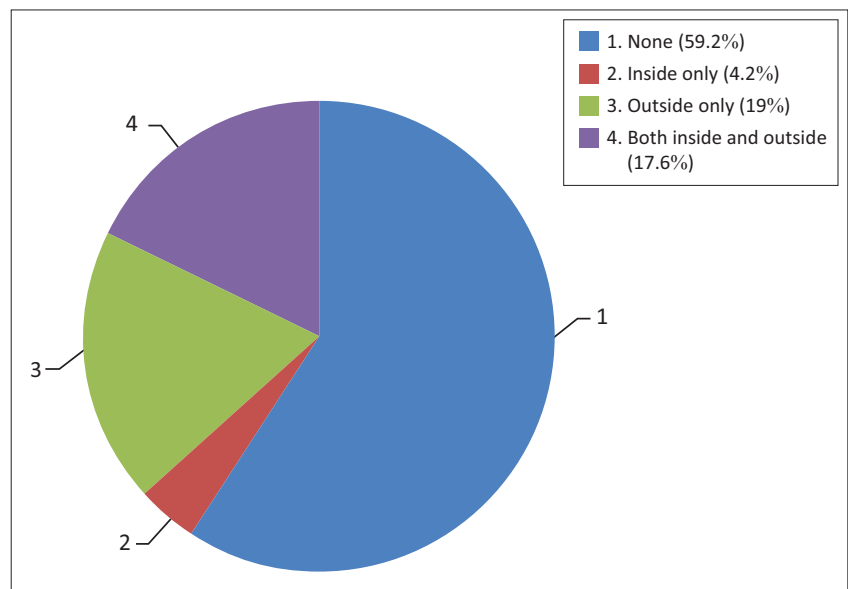

$n=142$.

FIGURE 1: Clergy's involvement in HIV and/or AIDS work. provided both inside as well as outside the clergy's congregations.

Prevention: Educational and HIV and/or AIDS prevention programmes for adults were offered by $18.3 \%$ of the participants, mainly outside their own congregations. HIV and/or AIDS prevention programmes for young people were provided by $19.7 \%$ of clergy, both inside as well as outside their own congregations. The same percentage of clergy (19.7\%) encouraged people to go for HIV and/or AIDS counselling and testing. About 19\% had discussions about respecting the female body with boys and young men (mainly inside the congregation). A surprisingly low number of clergy (17.6\%) were involved in HIV and/or AIDS awareness days, for example World AIDS Day on 01 December. Only 6.3\% gave attention to HIV and/or AIDS awareness days inside their own congregations, while 8.5\% were involved in HIV and/or AIDS awareness days both inside and outside their own congregations. Very few clergy (14.8\%) were involved in HIV and/or AIDS prevention programmes for employees who work in homes, gardens or who look after parishioners' children. Those who offered prevention programmes for these employees did so mainly outside their own congregations (9.2\%), with only 3.5\% clergy offering programmes both inside and outside their congregations and $2.1 \%$, who offered prevention programmes for workers exclusively in their own congregations.

HIV and/or AIDS disease management: A health or HIV and/or AIDS clinic was supported by $14.8 \%$ of the clergy, while $12.7 \%$ supported antiretroviral (ARV) support groups where patients were encouraged to adhere to their medications. Both support of clinics and ARV adherence groups were mainly offered outside of the congregation. It should be mentioned that $5.6 \%$ supported or offered ARV adherence programmes in their own congregations.

Clergy who were involved in HIV and/or AIDS work were significantly more inclined to agree that HIV and/or AIDS is a problem in the Afrikaans-speaking churches in general $(U=1609, z=-3.356, p=0.001$, md 2.6 versus 2.4$)$, as well as in their own congregations $(U=1969.5, z=-2.108, p=0.035$, mean ranks 79.54 versus 65.95).

TABLE 1: Type and places of involvement in HIV and/or AIDS projects.

\begin{tabular}{|c|c|c|c|c|}
\hline Involvement in HIV and/or AIDS projects & Inside parish, \% & Outside parish, $\%$ & Both inside and outside, $\%$ & Total involved, $\%$ \\
\hline Counselling of people infected by HIV & 10.6 & 1.4 & 9.1 & 21.1 \\
\hline Efforts to address and change stigma and negative attitudes & 7.7 & 2.8 & 9.9 & 20.4 \\
\hline Attention to HIV in sermons and prayer meetings & 10.6 & 3.5 & 5.6 & 19.7 \\
\hline Home care and assistance to the family (cooking, caring for children and transport to clinic) & 5.6 & 5.6 & 7.8 & 19.0 \\
\hline Help with subsistence (money, food and clothing) & 4.2 & 2.1 & 12.0 & 18.3 \\
\hline Support orphans & 3.5 & 8.5 & 7.7 & 19.7 \\
\hline HIV educational and prevention programmes (adults) & 4.9 & 9.9 & 3.5 & 18.3 \\
\hline HIV educational and prevention programmes (youth) & 7.1 & 6.3 & 6.3 & 19.7 \\
\hline Encourage people to go for HIV counselling and testing & 8.5 & 2.8 & 8.5 & 19.7 \\
\hline Talk to men and boys about respecting the female body & 8.5 & 2.8 & 7.7 & 19.0 \\
\hline HIV and/or AIDS awareness days (e.g. World AIDS Day on 01 Dec) & 6.3 & 2.8 & 8.5 & 17.6 \\
\hline HIV educational and prevention programmes (workers in gardens, homes and child minders) & 2.1 & 9.2 & 3.5 & 14.8 \\
\hline Support a health or an HIV clinic & 2.1 & 7.7 & 5.0 & 14.8 \\
\hline Antiretroviral support groups & 4.2 & 7.0 & 1.4 & 12.7 \\
\hline
\end{tabular}


Confidentiality issues and the stigmatisation of people with HIV and/or AIDS were some of the reasons why some clergy in the Afrikaans-speaking churches were reluctant to get involved in HIV and/or AIDS projects. The majority (77.5\%) believed HIV-positive people in their congregations would probably be hesitant to come forward for help because of confidentiality issues. Many (62\%) further believed that HIV and/or AIDS programmes should not be offered inside local parishes because it would result in stigmatisation of the attendees by the other parishioners. Some clergy (16.2\%) were also of the opinion that it is 'dangerous' for clergy to get involved with HIV and/or AIDS in their own congregations because they might also be stigmatised through association with the disease (secondary stigmatisation).

\section{Main education and prevention message}

Clergy were asked to choose the most appropriate and theologically sound message about the prevention of HIV and/or AIDS that they were prepared to share with their adult parishioners (see Table 2). (Prevention messages to young people will be discussed in a future article.)

As can be seen in Table 2, the main messages that clergy were prepared to share with the adult members of their parishes on how to prevent HIV infection were the strict church doctrines: (1) our bodies are the temple of God and should not be violated $(69.7 \%)$, (2) total abstinence outside marriage $(14.1 \%)$ and (3) sex outside marriage is sin (7.1\%). Not one participant was prepared to tell parishioners that condoms should be used 'should they sin and have sex outside the marriage'. The negative attitude towards condoms was further illustrated by the finding that $40.9 \%$ of clergy believed that to talk about condoms will undermine the main message of the Church, namely abstinence and faithfulness, and that any talk about condoms will promote promiscuity. A small percentage $(2.8 \%)$ of clergy indicated that sex should be expressed in a responsible way (but did not explain what that means) or said that various prevention messages are appropriate (e.g. total abstinence, but if not possible then restriction of number of partners with condom use).

\section{Beliefs about HIV and/or AIDS}

Some clergy believed that being religious will 'protect' people from HIV infection. Almost half of the clergy (48.6\%) believed that religious people will be less inclined to have extra-

\begin{tabular}{lc} 
TABLE 2: HIV and/or AIDS prevention message to adult parishioners. & \\
\hline HIV and/or AIDS prevention message to adult parishioners & $\%$ \\
\hline $\begin{array}{l}\text { Your body is the temple of God and therefore you have to live a healthy } \\
\text { life on all levels, also on the sexual level }\end{array}$ & 69.70 \\
\hline $\begin{array}{l}\text { Total abstinence outside marriage } \\
\text { Sex outside marriage is sin }\end{array}$ & 14.10 \\
$\begin{array}{l}\text { Faithfulness to one sex partner at a time (also called 'serial' monogamy) } \\
\text { with condom use }\end{array}$ & 5.10 \\
$\begin{array}{l}\text { Restrict your number of sex partners to the minimum } \\
\begin{array}{l}\text { All people sin from time to time. It is therefore important to use condoms } \\
\text { if you have sex outside marriage }\end{array}\end{array}$ & 0.00 \\
\hline Other (e.g. responsible expression of sex; combination of above) & 2.80 \\
\hline$n=142$. &
\end{tabular}

marital sex than non-religious people, while $37.3 \%$ believed that religious people's chances to get HIV infected are much less than that of non-religious people. Some clergy (13.4\%) believed that it was not necessary to provide parishioners with any information about HIV and/or AIDS prevention because 'my parishioners know that sex outside marriage is $\sin ^{\prime}$, and $47.9 \%$ believed that a message of 'total sexual abstinence outside marriage will be enough to prevent HIV infection'. This denial of the problem contradicts to some extent the belief of $36.6 \%$ of clergy that sex outside marriage is a common occurrence in their parishes.

\section{Discussion and recommendations Is HIV and/or AIDS a problem?}

Although most of clergy who participated in this study still believed that HIV and/or AIDS is a much bigger problem outside the Afrikaans-speaking church than inside, there is growing awareness that is not 'a black problem' only. It is especially female clergy and clergy with higher educational levels who recognised that HIV and/or AIDS is also a problem in the Afrikaans-speaking churches in general, while clergy from the APK did not see HIV and/or AIDS as 'our problem' at all.

In contrast to what they believed about the church in general, not many clergy were prepared to see HIV and/or AIDS as a problem in their own parish. Most believed that the HIV and/or AIDS problem is so small in their own congregations that it can be completely ignored, even though more than $60 \%$ of them said that they know or suspect that some people in their congregations are infected with HIV. These apparent contradictions are typical examples of projection, used as a psychological defence mechanism, where a person tries to remove a potential threat or problem as far as possible from themselves and their in-group (i.e. own congregation) (Sherwood 1981:445).

\section{Support from the church and empowerment}

The perception of most clergy was that they do not get enough guidance from church leaders and their synods with regard to HIV and/or AIDS, and they wanted more support and training. Most of the clergy in the current study (66\%), who were involved in HIV and/or AIDS projects, said that they had to do their own research if they wanted to know anything about HIV and/or AIDS and how it should be managed in their congregations. This may be one of the reasons why more than a third of the clergy were still uncertain or felt not sufficiently empowered to provide HIV and/or AIDS counselling and education.

It is, however, interesting to note that $40.1 \%$ of the participants explicitly stated they do not want any guidance or information from the church, either because they were not interested, or because they already have enough knowledge. Of these, $60 \%$ were very outspoken and said that it is not the task of clergy or the church to educate their parishioners about high-risk behaviour or the prevention of HIV infection, or even to take 
care of people with HIV infection. These services should be provided by the medical profession and not the church and the task of clergy is merely to refer patients to doctors, hospitals and clinics.

\section{Level and nature of involvement in HIV and/or AIDS projects}

The results of this study showed a positive shift in Afrikaansspeaking churches' involvement in HIV and/or AIDS projects compared to Schoeman's survey in 2006 (Schoeman 2012:1-8). While only 10\% of congregations were involved in HIV and/or AIDS and poverty projects in Schoeman's study, $41 \%$ of clergy in the current study were involved in HIV and/ or AIDS projects. While there was still the tendency (in the current study) to rather get involved in projects outside one's own congregation, there was nonetheless some increase in clergy's involvement in projects inside their own congregations. While only 3\% of HIV and/or AIDS work was performed in their own congregations in 2006 (Schoeman 2012), 4.2\% clergy in the current study were involved in HIV and/or AIDS work exclusively in their own congregations, while an additional $17.6 \%$ said that they were involved in projects inside as well as outside their own congregations making it a total of $21.8 \%$ who were involved inside their own congregations. It should, however, be taken into account that Schoeman's study investigated only the NGK in 2006, while the current study explored the involvement in HIV and/or AIDS projects of four Afrikaans-speaking churches in the Reformed tradition 10 years later. Because Schoeman's study formed part of an official NGK study, the number of participants in his study was also significantly higher than in the current study.

The perception that stigma and discrimination are barriers to access support was expressed by almost $80 \%$ of clergy, who believed that HIV-infected people in their own congregations will not ask for their help because they fear being stigmatised. Stigma and discrimination was also one of the reasons why more than $60 \%$ clergy believed that HIV and/or AIDS programmes should not be offered within one's own congregation, but always outside in the wider community. In their study on perceptions amongst South African church goers, Van Dyk and Van Dyk (2007:686) found that although HIV-infected black people $(82 \%)$ were more willing to go to their priests or ministers for support than white people (64\%), it is wrong to think that no white parishioners will come forward for help. Clergy need to do self-reflection and ask themselves if they are not using stigma and discrimination as an excuse not to get involved in HIV and/or AIDS projects. Clergy should also reflect on their own attitudes towards people who are infected with HIV. The finding that some clergy avoided HIV and/or AIDS work because they feared that any association with HIV and/or AIDS will also stigmatise them is an example of such negative attitudes.

Although 59\% congregations had no HIV and/or AIDS projects inside or outside their parishes, there was some improvement in local congregations' involvement in HIV and/or AIDS projects over the last 10 years since 2006. It is therefore not possible to agree with Schoeman (2012:7) that there is a growing movement towards non-involvement in social issues (specifically HIV and/or AIDS and poverty), but the low level of involvement in social projects is nonetheless lamentable. If Denis (2009:69) is correct that the fight against HIV and/or AIDS (including behaviour change, stigma reduction, higher levels of disclosure, care and treatment and ongoing support to people living with HIV and/or AIDS) will ultimately be won or lost at the local parish level, then this low involvement in HIV and/or AIDS projects (at the parish level) should be a matter of concern to the church. The church can make a huge contribution to the well-being of its parishioners as well as to society in general, but they should first accept that the congregation is not only a sacred place, but also a civic place with the responsibility to take care of all aspects of the community (Ammerman 1999). For the church to stay relevant in a changing society, strong leadership is needed to address all social, physical and other issues their parishioners are confronted by.

The nature of the HIV and/or AIDS projects that clergy were involved in corresponds to what Denis (2009:66-68) called 'a mitigating' response, rather than a response to 'reduce the progression' of disease. A mitigating response refers to taking care of the sick and needy - a process in which the church historically excelled. However, when it comes to prevention of a disease (reduction of the progression) the church is mainly silent in its response. This view of Denis was supported by the findings of this study in that clergy were most actively involved in supporting and counselling those who were already infected. This included physical support, financial help, home-based care, orphan care and in some cases, support of clinics and ARV adherence programmes.

However, when it came to prevention, there was a serious lack of involvement in prevention programmes, especially within their own congregations. Less than $10 \%$ of clergy were involved in HIV and/or AIDS awareness campaigns (like World AIDS Day), or in HIV and/or AIDS education and prevention programmes in their own congregations. HIV and/or AIDS prevention programmes for parish employees like gardeners, cleaners, housemaids or child minders were almost non-existent. This corresponds to the earlier findings of Van Dyk and Van Dyk (2007:682-697) that, within the broader South African church community (Protestant, Pentecostal, Roman Catholic and African Initiated Churches), the church did well in providing general relief, care and welfare services to HIV-positive parishioners, but not so much in prevention.

According to Scott (1980) and Swart (2006:98-103) the social involvement of the church can be divided into four development phases: The first phase entails providing relief and welfare serves to those in need, while the second phase moves beyond that to the development of leadership and empowerment of clergy as well as the congregation to cope with new challenges. The third phase entails being on the 
forefront of advocacy, policy change and the development of sustainable systems and the fourth, and final stage, would be the development of people's potential within a healthy and sustainable environment.

There is no indication from the results of the current study that the Afrikaans-speaking churches in the Reformed tradition is fighting unjust social systems at the higher levels of social involvement to ensure a better life for people living with HIV and/or AIDS. A mere $40 \%$ of parishes were at all involved in HIV and/or AIDS projects and then almost entirely at Scott (1980) and Swart's (2006) first and to a lesser extent second level of involvement. That is, their reaction to the crisis was 'putting out the fire' instead of being proactive by empowering clergy and the congregation on how to prevent HIV and / or AIDS, on how to develop and implement clear policy and a realistic theology of HIV and/or AIDS. Not much has therefore changed since Schoeman's (2012:1-8) survey in the NGK Church in 2006, which found that only some movement towards the second developmental phase of community engagement was evident.

\section{Main prevention message}

Sermons and prayer meetings can potentially play a very important role in helping parishioners living with HIV and/ or AIDS and to cope with illness. Unfortunately, what is said at these occasions and how it is said can sometimes cause HIV-infected parishioners to feel more marginalised and rejected by the church (Streets 2008:832, 2013:206). Only 20\% of clergy who participated in this study gave attention to HIV and/or AIDS issues in sermons and in prayer meetings. Although the nature and content of sermons and prayers were not reported, the deduction can be made (from attitudes and believes reported in other sections of the questionnaire) that these messages are mainly moralistic. When asked what the main HIV and/or AIDS prevention message would be that they were prepared to share with adult members of their parishes, the majority $(70 \%)$ echoed the strict church doctrine that 'the body is the temple of God, which should not be violated'. Others believed that messages of 'total sexual abstinence, outside marriage' and 'sex outside marriage is sin' will be enough to prevent HIV infection. Not one minister was prepared to talk about condoms and only one would advise parishioners to restrict their number of partners to the minimum while also using condoms.

Although the theological dilemma in which the clergy find themselves, in this case, can be appreciated, it is nonetheless pertinent to note that this approach in preventing HIV infection (moralistic messages) is at complete loggerheads with the theories of behaviour change as proposed by social scientists. One of the basic principles underlying theories of behaviour change is that a person can only change his or her behaviour if that person knows exactly what behaviour to change (e.g. unprotected sex or sex without a condom) and how to change that behaviour (e.g. to use a condom every time the person has sexual intercourse) (Ajzen 1991, 2005; Fishbein \& Middlestadt 1989; Van Dyk, Tlou \& Van Dyk 2017:186-208). The message of behaviour change should be explicit and clear. It is therefore doubtful if the main moralistic message advocated by the clergy (the body as temple of God) would be effective because of its vagueness and lack of clear practical guidelines of what a person should do to change his or her behaviour. A message of 'total abstinence' is unrealistic (and not helpful) in a society where parish members (i.e. religious people), similar to the rest of the society, do sometimes have multiple sex partners outside marriage. South African statistics clearly confirm that HIV and/or AIDS does not discriminate between people on grounds of church affiliation, race or other attributes (Shisana et al. 2014). It is therefore just not true that religiousness in a person would guarantee protection from HIV infection. To advocate only abstinence and faithfulness, and to associate HIV and/or AIDS with sexual promiscuity and sin, can also have the unintentional effect of encouraging denial, nondisclosure, non-treatment, stigma and discrimination amongst members of the congregation.

It is interesting to note that clergy still advocate their strict moralistic message, while almost $40 \%$ of them believe that sex outside marriage is a general occurrence in their parishes - implying that their previous moralistic message was not very effective. Off course adherence to the Christian norms of sexual behaviour will reduce the risk of HIV infection in some members, but it is just unrealistic to expect all members in a parish to strictly adhere to these norms. To then reject these 'sinners' and not to care about them would fly against two of the most important pillars of the Christian belief: compassion and forgiveness.

\section{Conclusion}

Although the findings of this study cannot be generalised to all Afrikaans-speaking churches in the Reformed tradition, it gives some indications of how the church is dealing with HIV and/or AIDS in her own congregations. A small number of clergy took it on themselves to provide HIV counselling, care and education with minimum support from church leaders. When it came to HIV and/or AIDS prevention most clergy were only prepared to preach abstinence and faithfulness. Ultimately the choice for clergy would be to either remain drawn back in their comfortable idealistic view that a moralistic message is enough to protect their parishioners, or to care enough to step out of their comfort zone and confront reality by doing everything in their power to protect their flock - even those who sometimes tend to wander away from the straight and narrow.

Finally, it can be concluded that the Afrikaans-speaking churches have not completely ignored the warning of James 2:15-16 (quoted at the start of this article), but much more need to be done in practical terms to avoid our brothers and sisters from wandering around, hampered by poverty and disease.

\section{Acknowledgements Competing interests}

The author declares that she has no financial or personal relationships that may have inappropriately influenced her in writing this article. 


\section{References}

Ajzen, I., 1991, 'The theory of planned behaviour', Organizational Behaviour and Human Decision Processes 50, 179-211. https://doi.org/10.1016/0749-5978(91)90020-T

Ajzen, I., 2005, Attitudes, personality and behaviour, Open University Press, Berkshire.

Algemene Kommissie vir die Diens van Barmhartigheid, 2002, 'Standpunt MIV en VIGS', in Handelinge van die Elfde Algemene Sinode van die Nederduitse Gereformeerde Kerk, pp. 534-555, Nederduitse Gereformeerde Kerk Algemene Sinode.

Ammerman, N.T., 1999, Congregation and community, Rutgers University Press, London.

Bryant-Davis, T., Ellis, M.U., Edwards, N., Adams, T.P., Counts, P., Arline-Bradley, S. et al., 2016, 'The role of the Black church in HIV prevention: Exploring barriers an best practices', Journal of Community and Applied Social Psychology 26(5), 388408. https://doi.org/10.1002/casp.2270

Coolican, H., 2004, Research methods and statistics in psychology, 4th edn., Hodder \& Arnold, London.

Denis, P., 2009, 'The church's impact on HIV prevention and mitigation in South Africa: Reflections of a historian', Journal of Theology for Southern Africa 134, 66-81.

Ferdinando, K., 2016, 'Towards a biblical and pastoral approach to illness in an African context with particular reference to HIV AIDS', Evangelical Review of Theology 40(2), 111-127.

Fishbein, M. \& Middlestadt, S.E., 1989, 'Using the theory of reasoned action as a framework for understanding and changing AIDS-related behaviours', in V.M Mays, G.M. Albee \& S.F. Schneider (eds.), Primary prevention of AIDS: Psychological approaches, pp. 93-110, Addison-Wesley, Reading, MA.

Gibbs, A., Campbell, C. \& Maimane, S., 2015, 'Can local communities "sustain" HIV/ AIDS programmes? A South African example', Health Promotion International AIDS programmes? A South African example', Health Pror
$30(1), 114-125$. https://doi.org/10.1093/heapro/dau096

Haspel, M., 2004, 'Christian sexual ethics in a time of HIV/AIDS - A challenge for public theology', Verbum et Ecclesia 25(2), 480-501. https://doi.org/10.4102/ve. v25i2.282

Janse van Rensburg, J., 2010, 'A holistic approach to pastoral care and poverty', Verbum et Ecclesia 31(1), 7p. https://doi.org/10.4102/ve.v31i1.386

Lasater, T.M., Wells, B.L., Carleton, R.A. \& Elder, J.P., 1986, 'The role of churches in disease prevention research studies', Public Health Reports 101(2), 125-131.

Mahlangu, E., 2011, 'The church's response towards orphans and vulnerable children as a result of HIV AIDS: A theological biblical perspective', Verbum et Ecclesia 32(1), 1-6. https://doi.org/10.4102/ve.v32i1.467

Moore, D., Onsomu, S.M., Abuya, B.A. \& Moore, C., 2012, 'Communicating HIV/AIDS through African American churches in North Carolina: Implications and recommendations for HIV/AIDS faith-based programs', Journal of Religion and recommendations for HIV/AIDS faith-based programs', Journal
Health 51, 865-878. https://doi.org/10.1007/s10943-010-9396-x
Ogunmefun, C., Gillbert, L. \& Schatz, E., 2011, 'Older female caregivers and HIV/AIDSrelated secondary stigma in rural South Africa', Journal of Cross-Cultural related secondary stigma in rural South Africa', Journal of Cross-Cu
Gerontology 26(1), 85-102. https://doi.org/10.1007/s10823-010-9129-3

Olivier, J., 2014, 'Mapping interdisciplinary communication between the disciplines of religion and public health in the context of HIV/AIDS in Africa', Religion and Theology 21(3-4), 251-289. https://doi.org/10.1163/15743012-02103003

Schoeman, L.G., Verster, P. \& Kritzinger, J.J., 2002, 'Die wit kerk en swart nood: Is daar nog sout in die soutpot oor? Opmerkings oor die betrokkenheid van die wit kerk by die MIV/Vigs pandemie in Suid-Afrika', Verbum et Ecclesia 23(2), 468-480. https://doi.org/10.4102/ve.v23i2.1220

Schoeman, W.J., 2012, 'The involvement of a South African church in a changing society', Verbum et Ecclesia 33(1), 1-8. https://doi.org/10.4102/ve.v33i1.727

Scott, W., 1980, Bring forth justice, Eerdmans, Grand Rapids, MI.

Sherwood, G.G., 1981, 'Self-serving biases in person perception: A reexamination of projection as a mechanism of defense', Psychological Bulletin 90(3), 445-459. hrtps://doi.org/10.1037/0033-2909.90.3.445

Shisana, O., Rehle, T., Simbayi, L.C., Zuma, K., Jooste, S., Zungu, N. et al., 2014, South African national HIV prevalence, incidence and behaviour survey, HSRC Press, Cape Town.

Stewart, J.M., Thompson, K. \& Rogers, C., 2016, 'African American church-based HIV testing and linkage to care: Assets, challenges and needs', Culture, Health \& Sexuality 18(6), 669-681. https://doi.org/10.1080/13691058.2015.1 106587

Streets, F.J., 2008, 'The pastoral care of preaching and the trauma of HIV and AIDS', Verbum et Ecclesia 29(3), 832-853. https://doi.org/10.4102/ve.v29i3.33

Streets, F.J., 2013, 'Preaching and the trauma of HIV and AIDS: A social work perspective', Social Work and Christianity 40(2), 206-224.

Swart, I., 2006, The churches and the development debate: Perspectives on a fourth generation approach, pp. 98-103, Sun Media, Stellenbosch.

Thomas, L.E., 2008, 'What the mind forgets the body remembers: HIV/AIDS in South Africa - A theological and anthropological issue', Currents in Theology and Mission 35(4), 276-286.

Timmons, S.M., 2009, 'Pastors' influence on research-based health programs in church settings', Journal of Health Disparities Research and Practice 3(2), 92-102.

Van Dyk, A., Tlou, E. \& Van Dyk, P., 2017, HIV and AIDS education, care and counselling: A multicultural approach, 6th edn., Pearson Education, Cape Town.

Van Dyk, P.J. \& Van Dyk, A.C., 2007, 'Does the church deliver? Perceptions amongst South Africans about the role of the church in the HIV/AIDS field', Verbum et Ecclesia 28(2), 682-697. https://doi.org/10.4102/ve.v28i2.127

Van Wyngaard, A., 2006, 'Towards a theology of AIDS', Verbum et Ecclesia 27(1), 265290. https://doi.org/10.4102/ve'v27i1.148 